\title{
Improving the Establishment and Yield of Soybean through Planting Depth and Land Preparation Methods in Northern Ghana
}

\author{
I. Y. D. Lawson'1, E. A. Mensah² and E. N. Yeboah² \\ ${ }^{1}$ Department Soil Science, University of Ghana, Box LG 245, Legon-Accra \\ ${ }^{2}$ Faculty of Agriculture, University for Development Studies, P. O. Box TL 1882, Tamale, Ghana
}

\begin{abstract}
Two field experiments, organized in randomized complete block design, were conducted in 2005 and 2006 farming seasons at Nyankpala in the Northern Region of Ghana to investigate the effects of planting depth (1, 2, 4, 6 and $8 \mathrm{~cm})$ and land preparation methods (flat field, mounding and ridging) on crop establishment (percentage number of established plants) and grain yield of soybean (Glycine max cv. Anidaso). In the 2005 farming season results indicated that crop establishment increased from planting depth of $1 \mathrm{~cm}(97.75 \%)$, reached a peak at $4 \mathrm{~cm}(98.82 \%)$ and declined through 6$8 \mathrm{~cm}$ (94.15\%) under flat field condition. Nodule formation was high between planting depth of 2 and $4 \mathrm{~cm}$. Generally, the number of pods and grain yield decreased with increasing plant depth. The grain yield values for 1, 2, 4, 6 and $8 \mathrm{~cm}$ depths were 4.25, 4.22, 3.87, 3.26 and 3.12 t/ha, respectively. In the 2006 farming season, at $4 \mathrm{~cm}$ planting depth ridging gave the highest crop establishment of $97.77 \%$. The highest number of pods was recorded for mound (197 per plant) followed by ridge (189 per plant) and flat (143 per plant). This pod formation characteristic reflected in the grain yield of $6.14 \mathrm{t} / \mathrm{ha}, 5.95 \mathrm{t} / \mathrm{ha}$ and $4.07 \mathrm{t} / \mathrm{ha}$ for mound, ridge and flat, respectively. The study revealed that for good crop establishment and optimum grain yield of soybean in northern Ghana planting could be done on mounds or ridges at planting depth between 1 and $4 \mathrm{~cm}$. Ridging may be preferred because it can easily be prepared mechanically using a tractor to save time and labour.
\end{abstract}

\section{Introduction}

In Ghana, soybean is cultivated mainly in the Northern, Upper West, Upper East, Central and Volta regions. Among these geographical regions, the largest production occurs in northern Ghana, which lies within the Guinea savanna and Sahel agro-ecological zones. The average yield for northern Ghana (Northern, Upper West and Upper East regions) was about 2.5 tonnes/ha on the farmers' field (Awuku, 1991) compared to that of USA which was 4.6 tonnes/ha (Richard et al., 1984). One of the factors contributing to low crop yields in northern Ghana is poor soil fertility, mainly due to low content of organic matter and nitrogen (Adu, 1969). Besides, one of the consequences of poor soil fertility in northern Ghana in the past few decades has been the falling agricultural productivity index (Dogbe, 1998).

Crop establishment is another problem and is often cited as a production problem for soybean in both arid and semi-arid areas of Central and West Africa (ICRISAT, 1984). Farmers are frequently obliged to resow several times to attain an acceptable stand of plants. However, resowing increases labour requirement for crop production, and the crops from late sowing often yield less than those sown with the first rains (Charreau, 1974). Thus, poor and irregular stand or crop establishment remains the major problem with farmers who cultivate on flat fields. Johnson \& Wax (1979) documented that cultural variables such as seedbed conditions, seed quality, and minor differences in planting depth are often the major variables causing stand problems. In the USA, the North Dakota State University (NDSU, 2008) reported that soybean should be planted at a depth of 2.5$3.75 \mathrm{~cm}$ and never deeper than $5 \mathrm{~cm}$. The National Soybean Research Laboratory (NSRL, 2008) of the USA also reported that the typical planting depths of soybean are $2.5-3.75 \mathrm{~cm}$, but if the soil is low in moisture or sandy, one should plant at $5 \mathrm{~cm}$ deep; and seldom should soybeans be planted deeper than $6.25 \mathrm{~cm}$.

In northern Ghana, attempts have been made by researchers to improve the characteristic growth and yield of soybean. For instance, chemical fertilizers have been applied with the aim of increasing crop establishment and yield of soybean (Asante, 1999). In another research work the use of spacing of 5 and $10 \mathrm{~cm}$ between plants and within row, respectively, and 60 and $75 \mathrm{~cm}$ had been used to improve establishment of soybean (Kaleem, 1986). Besides, the application of organic matter and inoculation with Bradyrhizobium japonicum were also used to enhance yield of soybean West African Journal of Applied Ecology, vol. 14, 2008 
(Lawson \& Quainoo, 2002). However, little attempts have been made using planting depth and land preparation methods to improve establishment and yield of soybean in northern Ghana. It is against this background that the present study was conducted with the aim to improve the crop establishment and yield of soybean through planting depth and land preparation methods in northern Ghana.

\section{Experimental site}

\section{Materials and methods}

The experiment was conducted at the Faculty of Agriculture Farm, University for Development Studies at Nyankpala in the Northern Region of Ghana. The area lies within the interior Guinea savanna of Ghana, which falls on latitude 9025'141”, longitude 0 58 '142” and at an altitude of 183 $\mathrm{m}$ above sea level. The area is characterized with natural vegetation dominated by grasses with few shrubs. The area has an average minimum temperate of $25^{\circ} \mathrm{C}$ and maximum average temperature of $35{ }^{\circ} \mathrm{C}$, with total annual monomial rainfall of about $1022 \mathrm{~mm}$. The soil was derived from Voltaian sandstone and classified as Nyankpala series (Plinthic Acrisol; FAO, 1988).

\section{Plant culture}

The experimental field was ploughed, harrowed and demarcated into plots in which each plot measured $2 \mathrm{~m} \times 4 \mathrm{~m}$. The plots were laid in four blocks with $1 \mathrm{~m}$ between blocks and $0.5 \mathrm{~m}$ between plots. During the 2005 farming season the test crop, soybean (Glycine max cv. Anidaso), was sown at planting depths of 1, 2, 4, 6 and $8 \mathrm{~cm}$ at two seeds per hill by the dibbling method at a planting distance of $60 \mathrm{~cm} \times 5 \mathrm{~cm}$ under flat field condition. During the 2006 farming season, the soybean was sown at $60 \mathrm{~cm} \times 5 \mathrm{~cm}$ on mounds (diameter $60 \mathrm{~cm}$ and height $30 \mathrm{~cm}$ ), ridges (height $10 \mathrm{~cm}$ ) and flat field at a planting depth of $4 \mathrm{~cm}$. The treatments were laid out in a randomized complete block design (RCBD). The plants were grown in the field to maturity period under rain fed condition without fertilization.

\section{Data collection and analysis}

The parameters taken were crop emergence (percentage number of emerged seedlings) crop establishment (percentage number of established plants at flowering), nodule number, dry matter (nodule, shoot and root biomass), number of pods and grain yield. All data collected were subjected to analysis of variance (ANOVA) using the Genstat package (Lawes Agric. Trust, 2002). Crop emergence and establishment data were transformed as described by Gomez \& Gomez (1976) before subjected to ANOVA. Treatment means were considered to be significantly different at $P \leq$ 0.05 .

\section{Crop emergence}

\section{Results}

Results have shown that planting between 1 and $4 \mathrm{~cm}$ gave high crop emergence values in the range of 94.14-96.60\% (Fig. 1). There was a sharp decrease in emergence below $4 \mathrm{~cm}$ depth. The least crop emergence was observed for seeds sown at a depth of $8 \mathrm{~cm}$ with a low crop emergence value of $19.58 \%$. Mounding and ridging the field significantly $(P<0.05)$ increased crop emergence by 3.95 and $10.61 \%$, respectively, when compared to the conventional sowing on flat land (Fig. 2). Ridging gave the highest crop emergence, and it was significantly $(P<0.05)$ different from mounding. 


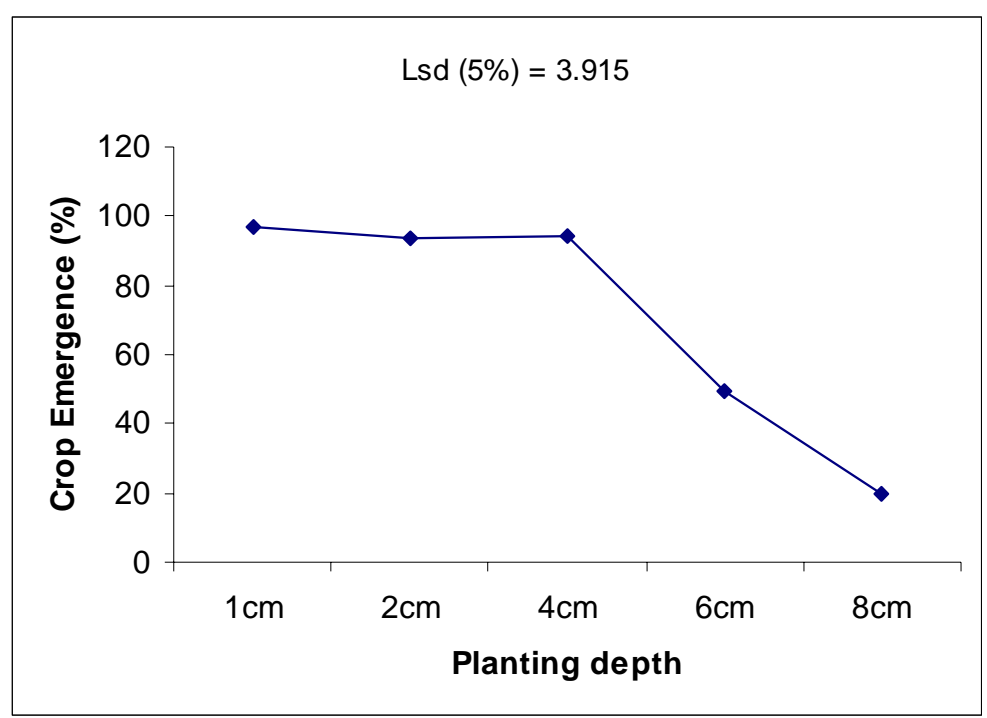

Fig. 1. Crop emergence at 6 days after planting

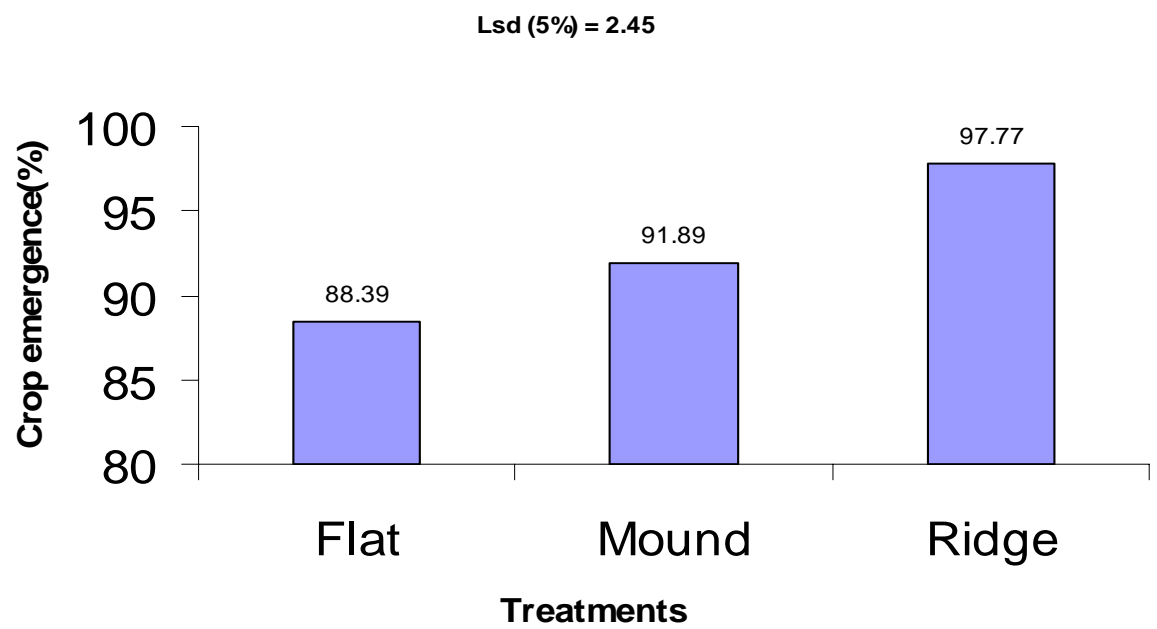

Fig. 2: Effects of land preparation methods on seed emergence.

\section{Crop establishment}

Results indicated that crop establishment was in the range of $94.15-98.82 \%$ when soybean was planted at different depths (Fig. 3). Crop establishment slightly increased from the depth of $1 \mathrm{~cm}$ and reached a peak of $98.82 \%$ at a depth of $4 \mathrm{~cm}$. This trend then decreased to a value of $94.15 \%$ at a depth of $8 \mathrm{~cm}$. There was no significant $(P>0.05)$ difference in crop establishment among 1,2 and $4 \mathrm{~cm}$ planting depths. Mounding and ridging increased crop establishment by 4.40 and $6.43 \%$, respec-tively, when compared to the conventional sowing on flat land (Fig. 4). However, there was no significant $(P>0.05)$ difference between plants cultivated on flat field and mounds. 


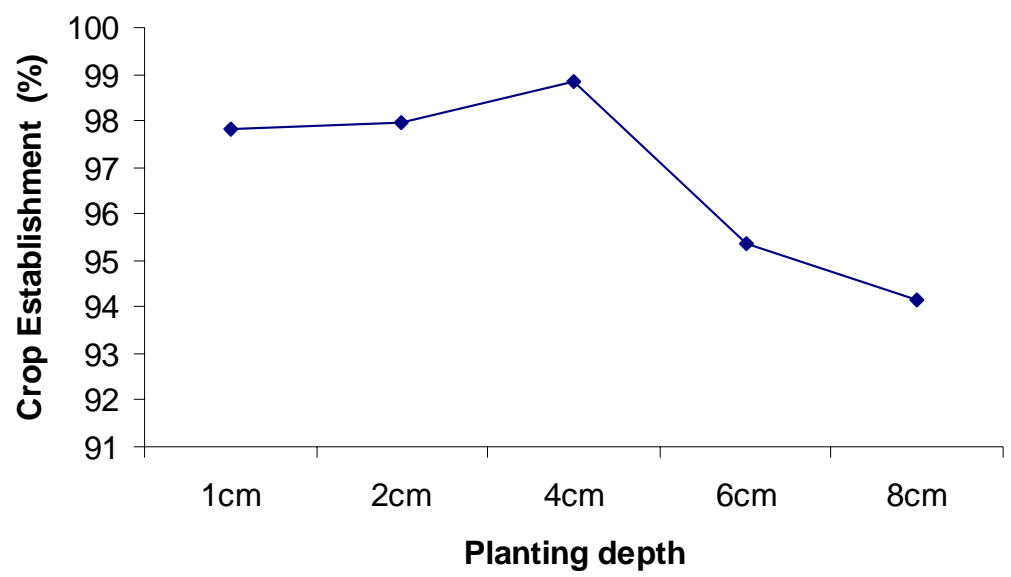

Fig. 3. Crop establishment at different planting depths

$\operatorname{Lsd}(5 \%)=5.72$

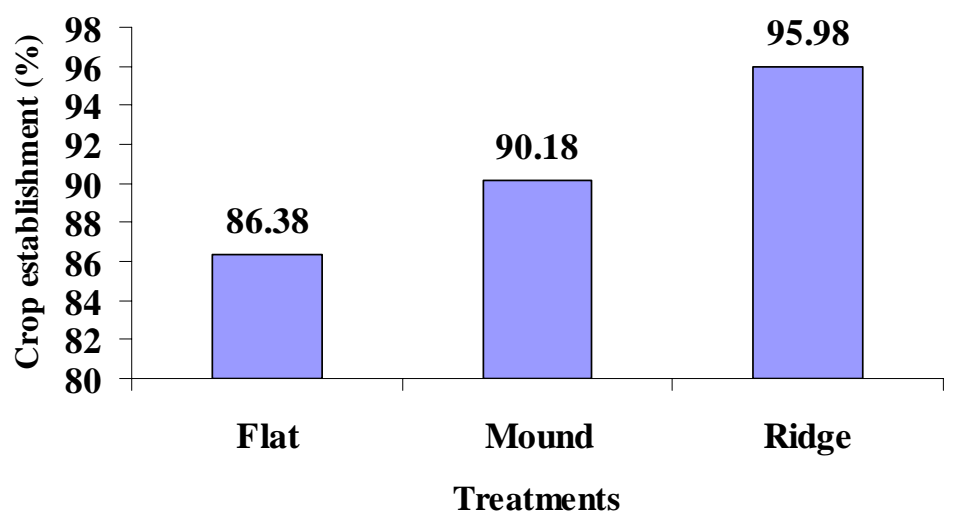

Fig. 4: Effects of land preparation methods on crop establishment.

\section{Nodule count}

Mean nodule number increased from planting depth of 1-4 cm and declined sharply with further increase in planting depth (Table 1). The highest number was recorded for $4 \mathrm{~cm}$ followed by 2 and $1 \mathrm{~cm}$ in that order; however, there was no significant $(P>0.05)$ difference among these treatments. The nodule dry weight followed the same pattern as the nodule count (Table 1). Ridging gave the highest mean nodule number followed by mounding and flat field (Table 2). However, mounding gave the highest mean nodule dry weight followed by ridging and flat field. The mean nodule dry weight for the mounds was significantly $(P<0.05)$ higher than that of ridges and flat fields, however, there was no significant $(P>0.05)$ difference between ridges and flat fields.

TABLE 1

Effect of planting depth on nodule number and dry weight

$\begin{array}{lcc}\begin{array}{l}\text { Planting } \\ \text { depth }(\mathrm{cm})\end{array} & \begin{array}{c}\text { Mean nodule } \\ \text { number } \\ \text { per plant }\end{array} & \begin{array}{c}\text { Mean nodule } \\ \text { dry wt }(\mathrm{g}) \\ \text { per plant }\end{array} \\ 1 & 4.88 & 0.80 \\ 2 & 6.62 & 1.09\end{array}$




\begin{tabular}{|c|c|c|}
\hline 4 & 7.25 & \\
\hline 6 & 2.12 & \\
\hline 8 & 3.12 & \\
\hline LSD (5\%) & 3.55 & 0.60 \\
\hline
\end{tabular}

TABLE 2

Effect of land preparation on nodule number and dry weight

$\begin{array}{lll}\begin{array}{l}\text { Land } \\ \text { preparation } \\ \text { method }\end{array} & \begin{array}{l}\text { Mean nodule } \\ \text { number } \\ \text { per plant }\end{array} & \begin{array}{l}\text { Mean nodule } \\ \text { dry wt }(\mathrm{g}) \\ \text { per plant }\end{array} \\ \text { Flat } & 2.25 & 0.19 \\ \text { Mound } & 2.90 & 0.30 \\ \text { Ridge } & 3.33 & 0.21 \\ \quad \text { LSD (5\%) } & 2.45 & 0.06\end{array}$

\section{Root and shoot biomass}

Results showed that there was no significant $(P>0.05)$ difference in root biomass between 1 , 2 , 4 and $6 \mathrm{~cm}$. However, at $8 \mathrm{~cm}$ depth root biomass significantly $(P<0.05)$ increased when compared with the other treatments (Table 3). Shoot biomass was in the range of 48.5-58.5 g per plant. The highest and least shoot biomasses were observed for seeds planted at depths of $6 \mathrm{~cm}$ and $1 \mathrm{~cm}$, respectively. However, there was no significant $(P>0.05)$ difference among the treatments. The highest total biomass was recorded for $8 \mathrm{~cm}$ followed by $6 \mathrm{~cm}$, and $1 \mathrm{~cm}$ scored the least value. However, there was no significant $(P>0.05)$ difference among the treatments. Mounds gave the highest biomass followed by ridges and flat (Table 4$)$, however, there was no significant $(P>0.05)$ difference among the treatments.

TABLE 3

Effect of planting depth on shoot and root biomass

$\begin{array}{cccc}\begin{array}{c}\text { Planting } \\ \text { depth } \\ (\mathrm{cm})\end{array} & \begin{array}{c}\text { Mean root } \\ \text { biomass } \\ \text { (g/plant) }\end{array} & \begin{array}{c}\text { Mean shoot } \\ \text { biomass } \\ \text { (g/plant) }\end{array} & \begin{array}{c}\text { Mean total } \\ \text { biomass } \\ \text { (g/plant) }\end{array} \\ 1 & 4.11 & 48.50 & 52.50 \\ 2 & 5.51 & 55.00 & 61.50 \\ 4 & 4.03 & 53.50 & 56.50 \\ 6 & 3.82 & 58.50 & 62.30 \\ 8 & 7.04 & 57.80 & 64.10 \\ \text { LSD (5\%) } & 2.10 & 12.49 & 11.39\end{array}$

TABLE 4

Effect of land preparation on shoot and root biomass

$\begin{array}{cccc}\begin{array}{c}\text { Land } \\ \text { preparation } \\ \text { method }\end{array} & \begin{array}{c}\text { Mean root } \\ \text { biomass } \\ \text { (g/plant) }\end{array} & \begin{array}{c}\text { Mean shoot } \\ \text { biomass } \\ \text { (g/plant) }\end{array} & \begin{array}{c}\text { Mean total } \\ \text { biomass } \\ (\mathrm{g} / \text { plant })\end{array} \\ \text { Flat } & 4.75 & 52.80 & 57.55 \\ \text { Mound } & 6.29 & 67.30 & 73.59 \\ \text { Ridge } & 5.00 & 55.50 & 60.50 \\ \text { LSD (5\%) } & 2.67 & 26.24 & 28.42\end{array}$

Yield and yield components 
The number of pods generally decreased with increasing planting depth (Table 5). However, there was no significant $(P>0.05)$ difference between the treatments. The highest pod number was recorded for $1 \mathrm{~cm}$ depth. Ridging and mounding significantly $(P<0.05)$ increased pod formation (Table 6). Mounding gave the highest number of pods, however, it was not significantly $(P>0.05)$ different from ridging. Grain yield also decreased with increasing planting depth (Table 5). However, there was no significant $(P>0.05)$ difference between the treatments. In the case of land preparation, mounding and ridging significantly $(P<0.05)$ increased grain yield (Table 6). Mounding gave the highest grain yield, however, it was not significantly $(P>0.05)$ different from ridging.

TABLE 5

Effect of planting depth on number of pods and grain yield

$\begin{array}{ccc}\begin{array}{c}\text { Planting } \\ \text { depth }(\mathrm{cm})\end{array} & \begin{array}{c}\text { Mean number } \\ \text { of pods } \\ \text { per plant }\end{array} & \begin{array}{c}\text { Grain yield } \\ (\mathrm{t} / \mathrm{ha})\end{array} \\ 1 & 153.20 & \\ 2 & 119.90 & 4.25 \\ 4 & 107.70 & 4.22 \\ 6 & 103.20 & 3.87 \\ 8 & 106.70 & 3.26 \\ \text { LSD (5\%) } & 36.45 & 3.12 \\ \end{array}$

TABLE 6

Effect of land preparation on number of pods and grain yield

$\begin{array}{lcc}\begin{array}{c}\text { Land } \\ \text { preparation } \\ \text { method }\end{array} & \begin{array}{c}\text { Mean number } \\ \text { of pods } \\ \text { per plant }\end{array} & \begin{array}{c}\text { Grain yield } \\ (\text { t/ha })\end{array} \\ \text { Flat } & 142.9 & 4.07 \\ \text { Mound } & 197.30 & 6.14 \\ \text { Ridge } & 188.70 & 5.95 \\ \text { LSD (5\%) } & 22.93 & 0.98\end{array}$

\section{Discussion}

Planting soybean between the depth of 1 and $4 \mathrm{~cm}$ gave the highest crop emergence values in the range of 96.60-94.14\% but there was a decrease in emergence below $4 \mathrm{~cm}$ depth. Fehr et al. (1973) stated that the deeper the seed is placed in soil, the more energy is required to pull the cotyledons to the soil surface, hence, the longer it takes to emerge. Al-Ami et al. (1985) indicated that maximum seed germination for most crops, e.g. soybean, occurred at oxygen concentra-tion close to that of the ambient air. The low emergence for soybean seeds planted deeper than $4 \mathrm{~cm}$ in the present study confirms the findings of Chapman \& Carter (1976), Onwueme \& Sinha (1991) and NDSU (2008), who reported that the emergence of soybean seedlings decreases markedly if seeds are sown deeper than $5 \mathrm{~cm}$.

NDSU (2008) reported that the ability of the germinating soybean seedling to push through a crusted soil decreases with deeper planting; and percent emergence decreased with increasing planting depth. Mounding and ridging the field increased crop emergence by $3.95 \%$ and $10.61 \%$, respectively, when compared to the conventional sowing on flat land. The increase in crop emergence by mounding and ridging could be due to loosening of the soil. Yayock et al. (1988) reported that well pulverized seedbeds promote rapid seedling emergence as moist and fine soil particles in contact with seeds provide sufficient moisture for quick emergence. 
Crop establishment slightly increased for seeds sown to the depth of $1 \mathrm{~cm}$, reached a peak at 4 $\mathrm{cm}$ and then decreased at the depth of $8 \mathrm{~cm}$. The high crop establishment at $4 \mathrm{~cm}$ could be due to favourable soil conditions such as adequate moisture, oxygen, temperature, etc., which might have enhanced nutrient uptake by roots. Cavalievi \& Boyer (1982) stated that seedlings start to establish themselves when they begin to absorb water and plant nutrients, and intercept sunlight for photosynthesis. Results of present study have also shown that ridging and mounding enhanced crop establishment.

According to Rowland (1993), the traditional system of ridge cultivation is based on the principle of reduced or minimum tillage, combining the effects of several different operations (ploughing, harrowing and ridging) in a single operation to improve crop establishment. Charreau (1974) reported that under deep tillage, ploughing or land preparation method proved to be the most efficient tillage practice that enhanced crop establishment. The high crop establishment by the ridges might be attributed to high seed emergence as explained by conservation of moisture and provision of favourable temperature, aeration and plant nutrients. Rowland (1993) reported that ridges and mounds improve aeration for roots, and facilitate the growth and development of underground tuber and root crops and pods of legumes, when the crops are grown on ridges and mounds to conserve limited soil moisture. Wang et al. (2000) documented that conservation of moisture and maintenance of higher temperature within the soil profile are more favourable for soybean emergence and seedling development.

The nodule formation was low and this low performance could be due to low indigenous rhizobia in the soil. Mean nodule number increased slightly from planting depth of $1-4 \mathrm{~cm}$ and declined below $4 \mathrm{~cm}$ depth. The high nodule count within the 1-4 cm depth compared to 6 and 8 $\mathrm{cm}$ values could be attributed to favourable soil conditions such as temperature, adequate moisture and oxygen for root development and survival of rhizobia, since nodules are formed through association of roots and effective rhizobia. Ridging and mounding the field increased the number of nodules in soybean even though the values were low. Rowland (1993) reported that ridges and mounds improve aeration for root growth and development. Since rhizobium species are aerobic, these land preparation methods might have enhanced the survival and infection of the soybean roots. The enhanced root development could have resulted in soil exploitation and contact with the few rhizobium species available in the soil for nodule formation.

Generally, the number of pods per plant decreased with increasing plant depth. Grain yield also followed the same pattern. Mounding and ridging the field increased number of pods. Rowland (1993) reported that ridges and mounds improve aeration for roots, and facilitate the growth and development of pods of legumes. The increase in pod formation might be due to conservation of moisture and provision of favourable temperature, aeration and plant nutrients. Mounding and ridging the field also increased grain yield. Board et al. (1990) and Board \& Tan (1995) reported that soybean yield is influenced, to a large extent, by environmental factors and notably among them is land preparation on which the seeds are sown. The increase in yield by mounding and ridging in the present study could be attributed to enhance crop establishment and pod formation.

\section{Conclusion}

The study was conducted to improve the crop establishment and yield of soybean through planting depth and land preparation methods in northern Ghana. Crop establishment increased from planting depth of $1 \mathrm{~cm}$, reached a peak at $4 \mathrm{~cm}$ and declined through $6 \mathrm{~cm}$ to $8 \mathrm{~cm}$. Generally, the number of pods and grain yield decreased with increasing plant depth. Ridging gave the highest crop establishment. Grain yield of $6.14 \mathrm{t} / \mathrm{ha}, 5.95 \mathrm{t} / \mathrm{ha}$ and $4.07 \mathrm{t} / \mathrm{ha}$ were recorded for mound, ridge and flat, respectively. The study revealed that for good crop establishment and optimum grain yield of soybean in northern Ghana, planting could be done on mounds or ridges at planting depth between 1 and $4 \mathrm{~cm}$. Ridging may be preferred because it can easily be prepared mechanically using a tractor to save time and labour. 


\section{Acknowledgement}

The authors thank the Seed Unit of Ministry of Food and Agriculture (MoFA) in Tamale, Ghana, for the provision of soybean seeds.

\section{References}

Adu S .V. (1969). Soils of the Navrongo-Bawku area, Upper Region, Ghana. Soil Research Institute Memoir No. 5. CSRI-Soil Research Institite Kumasi, Ghana.

Al-Ami A. F., Bruzau F., Raymond P. and Saint-ges V. (1985). Germination, respiration and adenylate energy change of seeds at various oxygen partial pressures. Pl. Physiol. 79: 885-980.

Asante S. K. (1999). Response of soybean (Glycine max) to application of organic and inorganic fertilizers. (BSc. Dissertation). University for Development Studies, Tamale, Ghana. pp. 1-49.

Awuku K.A. (1991). Agricultural and environmental studies. Rebl. Evans Brothers Ltd, London. 334 pp.

Board J. E., Harville B. G. and Saxton A. M. (1990). Branch dry weight in relation to yield increases in narrow-row soybean. Agron. J. 82: 540-544.

Board J. E. and Tan Q. (1995). Assimilatory capacity effect of soybean yield components and pod number. Crop Sci. 35: 846-851.

Cavalieri A. J. and Boyer J. S (1982). Water potentials induced by growing in soybean hypocotyls. Pl. Physiol. 69: 492497.

Charreau C. (1974). Soils of tropical dry and wet climatic areas of West Africa and their use and management. Cornell University, Ithaca, New York.

Chapman S. R. and Carter L. P. (1976). Soybean. In Crop Production: Principles and Practice. Freeman, San Francisco. pp. 345-357.

Dogbe W. (1998). Green-manure crops for sustainable agriculture in the inland valleys of northern Ghana. In Cover Crops in West Africa contributing to Sustainable Agriculture. IDRC, IITA and Sasakawa Global 2000. (D. Buckles, A. Eteka, O. Osiname, M. Galiba and G. Galiano, ed.), pp. 213-215. Ottawa, Canada.

Gomez K. A. and Gomez A. A. (1976). Problem Data. In Statistical Procedures for Agricultural Research, 2nd edn. John Wiley and Sons. New York. pp. 304-307.

FAO (1988). Soil Map of the World, Revised Legend, Reprinted with corrections. World Soil Resources Report 60. FAO, Rome.

Fehr W. R., Burns J. S. and Gilman D. F. (1973). Soybean emergence under field conditions. Agron. J. 65: 740-742.

ICRISAT (1984). In Annual Report for 1983. Patancheru, India. pp. 303-305.

Johnson R. R. and Wax L. M. (1979). Soybean stand establishment and yield as affected by herbicides and cultural practices. Agron J. 71: 880-884.

Kaleem F. (1986). Assessment of nitrogen fixation of various crops in Northern Ghana. First Workshop on improving farming systems in the Savanna. Nyankpala, Ghana. p. 2.

Lawes Agricultural Trust (2002). Genstat, 6th edn. Rothamsted Experimental Station, Claredon Press, Oxford, UK.

Lawson I. Y. D. and Quainoo A. (2002). Response of soybean to organic matter application and inoculation with Bradyrhizobium japonicum in the Guinea savanna of Ghana. J. Ghana Sci. Ass. 4(1): 53-57.

NDSU (2008). Soybean planting depth is critical. http//www.ag.udsu.edu/procrop/syb/sybpdc05.htm.

NSRL (2008). Soybean production. http//www.nsr/uiuc.edu/aboutsoy/production02html.

Onwueme I. C. and Sinha T. D. (1991). Soybean. In Field crop production in tropical Africa, pp. 339-343. Tropical Centre for Agricultural and Rural Corporation. The Netherlands.

Richard J. D., Greub L. J. and Anlgren H. L. (1984). Crop Production, 5th edn. Prentice-Hall Inc. Englewood Cliffs, New Jersey. pp. 252-279.

Rowland J. R. J. (1993). Dry land farming in Africa. CTA, The Hague, Netherlands. 249 pp.

Wang D. M., Shannon C., Grieve C. M. and Yates S. R (2000). Soil water and temperature regimes in drip and sprinkler irrigation, and implications to soybean emergence. DOI:10.1016/S0378-3774(99)00057-8.

Yayock J. K., Lombin G. and Owunibi J. J. (1988). Crop Science and Production in Warm Climate, pp. $158-166$. MacMillan Intermediate Agricultural Series. MacMillan, London. 